\title{
Molecular profile of the Lynch Syndrome in the Republic of Macedonia
}

\author{
Marija Hiljadnikova-Bajro ${ }^{1}$, Toni Josifovski ${ }^{2}$, Milco Panovski ${ }^{2}$, \\ Aleksandar J. Dimovski* \\ ${ }^{1}$ Institute of Applied Biochemistry, Faculty of Pharmacy, University "Ss Cyril and Methodius", \\ Skopje, Republic of Macedonia \\ ${ }^{2}$ University Clinic for Digestive Surgery, Medical Faculty, University "Ss Cyril and Methodius", \\ Skopje, Republic of Macedonia \\ ${ }^{3 *}$ Center for Biomolecular Pharmaceutical Analyses, Faculty of Pharmacy, University "Ss Cyril and Methodius", \\ Skopje, Republic of Macedonia
}

Received: November 2012; Accepted: December 2012

\begin{abstract}
The most frequent type of hereditary colorectal cancer, the one occurring in the setting of the Lynch syndrome (LS) is considered a phenotypic manifestation of a germline defect in the mismatch repair mechanism i.e. in the MLH1, MSH2, MSH6 or PMS2 gene. Aiming towards establishment of a standardized protocol involving molecular analyses for diagnosis of this syndrome and developing a unique national register of families with hereditary colorectal cancer syndromes in the Republic of Macedonia, we began a prospective study to reveal the genetic defects among Macedonian patients with colorectal cancer (CRC) and identifying families with hereditary CRC.

A total of 53 patients fulfilling the revised Bethesda criteria for MSI-genetic testing were compared to 350 patients with sporadic CRC. The results reveal significant differences in age at diagnosis $(p=0.03)$, involvement of microsatellite instability $(p<0.0001)$ and localization of the tumor in respect to flexura lienalis $(\mathrm{p}=0.009)$ and suggest affiliation of the majority of the "Bethesda+" CRCs to the so called Familial Colorectal cancer Type X group. The molecular characterization of LS suspects identified the novel MLH1 c.392C $>$ G nonsense mutation with a possible founder effect in the Macedonian population, the MLH1 ex.3-12 deletion, as well as the c.244A $>\mathrm{G}$ mutation, IVS14$19 \mathrm{~A}>\mathrm{G}$ and IVS4+65A $>\mathrm{C}$ changes in $M L H 1$ without confirmed pathological significance. The observed high frequency ( $87.5 \%)$ of the Ile219Val (c.655A >G) variant in MLH1 among the LS suspects prompts further analyses to evaluate its involvement in the development of hereditary CRC by itself or as a risk modifying factor among the patients from the Republic of Macedonia.
\end{abstract}

Keywords: Colorectal cancer, Lynch syndrome, MLH1, microsatelite instability

\section{Introduction}

The most frequent hereditary form of colorectal cancer (CRC), responsible for 2-4\% of all CRC cases (Aaltonen, 1998; Jasperson, 2010) is the hereditary nonpolyposis colorectal cancer-HNPCC, later renamed to Lynch syndrome (LS). The autosomal dominant pattern of inheritance and

\footnotetext{
*adimovski@ff.ukim.edu.mk
}

tel/fax:++38923126054 penetrance of $85-90 \%$ are important features of this syndrome which is characterized by development of cancers at an early age (45 years on average), predominantly located proximally to flexura lienalis $(70 \%)$, frequent presentation of multiple synchronous or metachronous CRCs as well as an increased risk for extracolonic malignancies affecting the endometrium, ovaries, gaster, intestines, hepatobiliary tract, pancreas, brain and the upper urinary tract (Watson and Lynch, 1994; Aarnio et al., 1999), but some families present with breast cancers also (Risinger et al., 1996). 
The molecular definition of the Lynch Syndrome implies germline mutations in any of the mismatch repair (MMR) genes responsible for the basepair mismatch reparation during DNA replication as: $\mathrm{MLH1}$ and $\mathrm{MSH} 2$ carrying almost $90 \%$ of the mutations, MSH6 holding $10 \%$ of the genetic defects and rare mutations in EPCAM and PMS2.

The initial criteria for the establishment of a clinical diagnosis of LS, the so called Amsterdam I and II criteria (Vasen et al., 1991 and 1994) are based on the familial cancer history, but the revised Bethesda criteria for genetic testing for LS (Umar et al., 2004) are more sensitive and enable identification of LS cases resulting from de novo MMR genetic defects.

Approximately ten to fifteen percent of individuals with $\mathrm{CRC}$ and/or colorectal adenomas have diseased relatives (National Cancer Institute, 2012), but don't meet the criteria for clinical diagnosis of neither LS nor the syndrome of familial adenomatous polyposis. They are considered as cases with familial colorectal cancer (FCC), which might be caused by unidentified genetic factors, exposition of the family members to common environmental risk factors or by chance. Furthermore, families fulfilling the Amsterdam criteria for LS but lacking genetic MMR-defects i.e microsatellite instable tumors, are designated as familial colorectal cancer type X (FCC-X) (Jass, 2006; Mueller-Koch et al., 2005; Valle et al., 2007). The risk for development of CRC is lower among these patients (Lindor et al., 2005) but if a malignant transformation eventually occurs, the diagnosis is usually established at an older age (55 years on average) in comparison to the LS. Further investigations are needed for their precise characterization, but it is quite obvious that tumors arising in FCC-X families feature a specific pathological phenotype with less tumor-infiltrating leukocytes versus typical LS tumors. (Llor et al., 2005).

Currently, there aren't any officially published data on the incidence/prevalence of LS in the Republic of Macedonia and there isn't a unique national register of patients/ families with any of the hereditary colon cancer syndromes, which seriously obstruct the investigation and characterization of this type of hereditary cancer in our country and disable appropriate prevention/treatment. Hence, we began a prospective study to aid the establishment of standardized protocols involving molecular analyses for clinical diagnosis of the Lynch syndrome in our country.

\section{Materials and methods}

From a total of 403 randomly selected patients undergoing colectomy for resection of histopathologically confirmed CRC at the University Clinic for Digestive Surgery in Skopje, a cohort of 53 cases was selected based on fulfillment of the Bethesda clinical criteria for MSI testing and compared to a group of 350 cases with sporadic CRC. Detailed personal and familial history as well as relevant information on dietary and life-style habits were obtained by the responsible clinicians.

The molecular analyses were performed on samples of peripheral blood and fresh tumor tissues obtained by the surgical resection of the cancer. The DNA was isolated using Proteinase K digestion/ phenol- chloroform-isoamylalcohol extraction/ethanol precipitation, according to standard procedures (Sambrook et al., 1989).

The evaluation of the microsatellite instability was performed by a fluorescent multiplex PCR reaction employing the Bethesda five marker panel (Rodrigues-Bigas et al., 1997; Boland et al., 1998), followed by capillary gel electrophoresis and fragment analysis on the Applied Biosystems' genetic analyzer AbiPrism 310 .

All microsatellite instable cancers were evaluated for their MLH1-promoter methylation status using methylation-specific quantitative $\mathrm{PCR}$ reaction following a bisulfite DNA-conversion (Xiong and Laird, 1997) and tested for the BRAF V600E mutation (Davies et al., 2002), while the corresponding blood DNA samples were screened for large genomic deletions/duplications using the Multiplex Ligation- Dependant Probe Amplification (MLPA) kit reagents from MRC-Holland (Amsterdam, Netherlands) according to the procedure first described by Schouten et al. (2002)

Patients having microsatellite instable cancers without hypermethylated MLH1-promoters and BRAFV600E mutation, lacking large genomic defects but fulfilling the Bethesda criteria for MSI testing, were subjected to bidirectional sequencing of the $M L H 1$ and $M S H 2$ genes using the Applied Biosystems' BigDye Terminator v1.1 Cycle sequencing kit and subsequent sequencing analysis on the AbiPRism310.

For detection of an aberrant mRNA transcript we performed a Reverse transcription-polymerase chain reaction (RT-PCR) using the GeneAmp RNA PCR kit (Life technologies, Califormia, USA) on peripheral mononuclear RNA obtained by the acidic guanidine-phenol-chlorophorm extraction (Chomczynski and Sacchi, 1987).

The detailed conditions for the above reactions and the oligonucleotide sequences of the employed primers are available upon request.

\section{Results and Discussion}

The studied group was comprised of 53 younger patients diagnosed with "Bethesda +"colorectal cancer at an average age of 50 years and progressed mainly to clinical stage B or C. Ovarial, gastic, brain but also breast, hepatic and gall bladder malignancies were identified among the patients or their relatives. Three of these patients were previously diagnosed with endometrial cancer, which is considered one of the commonest extracolonic malignancies in LS, apart from the ovarial cancer (Cruz-Correa and Giardiello, 2002).

The genetic profile of the cancers within this patient group features high frequency of microsatellite instabili- 
ty $(30 \%)$. The comparison with the sporadic CRC cases (Table 1) reveals significant differences in age at diagnosis $(p=0.04)$, involvement of microsatellite instability $(\mathrm{p}<0.0001)$ and tumor localization in respect to flexura lienalis $(p=0.009)$ so that, MSI is 3.99 times more frequently present than MSS in cancers of LS suspects and they develop 2.19 times more frequently in proximal than distal colon, compared to cancers of sporadic cases. These findings comply with the common definitions of the Lynch Sy (Watson and Lynch, 1994; Aarnio et al., 1999), but the published data state an MSI-involvement in $90 \%$ of these cancers. The lower frequency $(30 \%)$ of MSI detected in our cohort, suggests that a significant proportion of these patients are not actually LS-cases but cases with FCC-X. These patients might be having the hereditary syndrome recently proposed by Valle et al. (2007), which is considered a separate entity from LS, featuring MSS tumors, development of colorectal but not other cancers and absence of multiple primary tumors. The vast majority of the hereditary cancers in our group suggest an existence of a yet unidentified gene, being responsible for the development of syndrome, but lacking the MMR activity.

Aiming towards an establishment of a national register of families with hereditary CRC syndromes in our country, we created an interactive computer database of CRC cases, available for access and use by the involved clinicians and laboratory investigators. Additionally, we designed a protocol for molecular confirmation of the LS among clinical suspects for the disease.

The algorithm for detection of MMR defects employed in our study was based on unselective MSI- testing of all CRCs, which had been proven as a cost effective approach in identification of individuals at an increased risk for LS (Palomaki et al., 2009), with a 93\% sensitivity for identification of tumors resulting from MMR-mutations (Shia, 2008). This type of genetic instability was identified among $11 \%$ of all CRCs. A total of 53 patients with "Bethesda+"tumors were subjected to MSI testing. Somatic changes as MMR-promoter hypermethylation and the BRAFV600E mutation are considered as strong negative predictors of MMR-deficiency (Parsons et al., 2012; Bouzourene et al., 2010; Bellizzi and Frankel, 2009) and were

Table 1. Comparison between colorectal cancers of patients fulfilling the Bethesda criteria for LS and sporadic cases.

\begin{tabular}{|c|c|c|c|c|c|}
\hline & $\begin{array}{c}\text { "Bethesda +" CRCs } \\
(\mathrm{n}=53)\end{array}$ & $\begin{array}{c}\text { Sporadic CRCs } \\
(\mathrm{n}=350)\end{array}$ & $\mathrm{M}_{2}-\mathrm{M}_{1}$ & & $\mathrm{p}$ \\
\hline \multicolumn{6}{|l|}{ Age } \\
\hline \multirow[t]{2}{*}{$\begin{array}{l}\text { Number }(\mathrm{n}) \text {, Arithmeticalmean } \\
(\mathrm{Ar}) \pm \text { standard deviation }\end{array}$} & $\mathrm{Ar}=50.27 \pm 13.16$ & $\mathrm{Ar}=60.39 \pm 10.78$ & 10.12 & & 0.04 \\
\hline & \multicolumn{2}{|c|}{ Number (frequency) } & OR & $95 \% \mathrm{CI}$ & $\mathrm{p}$ \\
\hline \multicolumn{6}{|l|}{ Gender } \\
\hline $\begin{array}{l}\text { Male } \\
\text { Female }\end{array}$ & $\begin{array}{l}28(0.52) \\
25(0.48)\end{array}$ & $\begin{array}{l}204(0.58) \\
146(0.42)\end{array}$ & 0.80 & \multirow[t]{2}{*}{$0.45-1.43$} & 0.45 \\
\hline \multicolumn{5}{|l|}{ Clinical Tumor Stage } & \\
\hline $\begin{array}{l}\text { A } \\
\text { B } \\
\text { C } \\
\text { D }\end{array}$ & $\begin{array}{c}2(0.06) \\
18(0.56) \\
9(0.28) \\
3(0.09)\end{array}$ & $\begin{array}{c}19(0.06) \\
120(0.41) \\
128(0.43) \\
27(0.09)\end{array}$ & 1.87 & $0.88-3.96$ & $0.09^{\mathrm{a}}$ \\
\hline \multicolumn{6}{|l|}{ Genetic instability } \\
\hline $\begin{array}{l}\text { MSI } \\
\text { MSS }\end{array}$ & $\begin{array}{l}14(0.30) \\
33(0.70)\end{array}$ & $\begin{array}{l}30(0.1) \\
282(0.9)\end{array}$ & 3.99 & $1.92-8.27$ & $<0.0001$ \\
\hline $\begin{array}{l}\text { BRAF V600E + } \\
\text { BRAF V600E - }\end{array}$ & $\begin{array}{l}1(0.02) \\
40(0.98)\end{array}$ & $\begin{array}{c}8(0.04) \\
188(0.96)\end{array}$ & 0.59 & $0.07-4.83$ & 0.61 \\
\hline \multicolumn{6}{|l|}{ Localization } \\
\hline $\begin{array}{l}\text { Proximal }^{\mathrm{b}} \\
\text { Distal }^{\mathrm{c}}\end{array}$ & $\begin{array}{l}23(0.44) \\
29(0.56)\end{array}$ & $\begin{array}{l}77(0.26) \\
213(0.74)\end{array}$ & 2.19 & $1.19-4.02$ & $<0.01$ \\
\hline $\begin{array}{l}\text { Colon } \\
\text { Rectum }\end{array}$ & $\begin{array}{l}35(0.67) \\
17(0.33)\end{array}$ & $\begin{array}{l}188(0.63) \\
109(0.37)\end{array}$ & 1.19 & $0.64-2.23$ & 0.58 \\
\hline
\end{tabular}

${ }^{a}$ comparison between $\mathrm{CRCs}$ of lower $(\mathrm{A}+\mathrm{B})$ and higher stage $(\mathrm{C}+\mathrm{D})$

b Proximal localization includes CRCs localized in the coecum, ascending and transversal colon

${ }^{c}$ Distal localization refers to CRCs localized in the descending colon, sigmoid colon and rectum 
evaluated in all MSI CRCs prior to the MMR-genetic analysis. Patients complying with the revised Bethesda criteria and carrying microsatellite instable tumors without evidence of neither somatic $M L H 1$-promotor hypemethylation nor BRAF-V600E mutation, were selected for genetic testing which included MLPA-analysis for detection of large genomic rearrangements in $M L H 1, M S H 2, P M S 2$ and MSH6 genes, followed by bidirectional DNA-sequencing of the 19 and 16 exons and flanking intronic regions of MLH1 and MSH2 respectively. Using this approach, we narrowed the selected group to 10 patients highly suspicious and suitable for LS-genetic testing. Mutations in the $\mathrm{MSH} 2$ gene were not detected but several genetic defects in $M L H 1$ were identified as most probable causative defects for LS.

We reported previously (Hiljadnikova-Bajro, 2012) the first molecular characterization of the Lynch Syndrome in the Republic of Macedonia by the identification of the nonsense MLH1 c.392C $>$ G mutation in two seemingly unrelated patients, and suspecting its founder effect suggested screening of all LS suspects from the region for this mutation by a Restriction Fragment Length Polymorphism test. Using this approach, we later identified another patient with the same mutation, who has distant familial relationship with one of the abovementioned index patients but wasn't included in the genetic counseling of the patient's family. This case highlights the necessity of presenting a thorough familial history by the patients and in case of identification of a LS patient, genetic counseling of all relatives at risk of cancer development in order to prevent or timely treat it.

Using the MLPA analysis, we detected quantitative changes at either single or multiple nonsuccessive exons in several patients, but these isolated changes probably result from variations within the probes's hybridization loci on the tested DNA leading to impaired hybridization and consequently decreased amplification of the corresponding fragments. But, in one pediatric patient, we detected a large deletion in $M L H 1$ targeting exons 3 through 12 (Fig. 1). The patient is an adolescent boy, diagnosed with two metasynchronous cancers of the transversal and sigmoid colon of stage IIa at the age of 15 and 16 years respectively. The molecular analyses revealed a microsatellite instable character of the cancers, but only one of them was suitable for BRAF and MLH1-hypermethylation testing and scored negative for the BRAF V600E mutation but exerted a high degree of $M L H 1$-promoter methylation. Exploring the familial history of the disease, we concluded that the MLH1genetic defect is most probably inherited from the mother, who was diagnosed with endometrial cancer few years ago. Genetic testing of the mother was offered and if performed in future, it should confirm or exclude this hypothesis. On the other hand, somatic $M L H 1$ promoter hypermethylation is associated with sporadic cases of MSI CRCs, opening a possibility though minor for different etiologies of the two cancers diagnosed in this patient: the first which is currently unavailable for promoter hypermethylaton-testing might be having a hereditary basis, and the other one with hyper-

a)

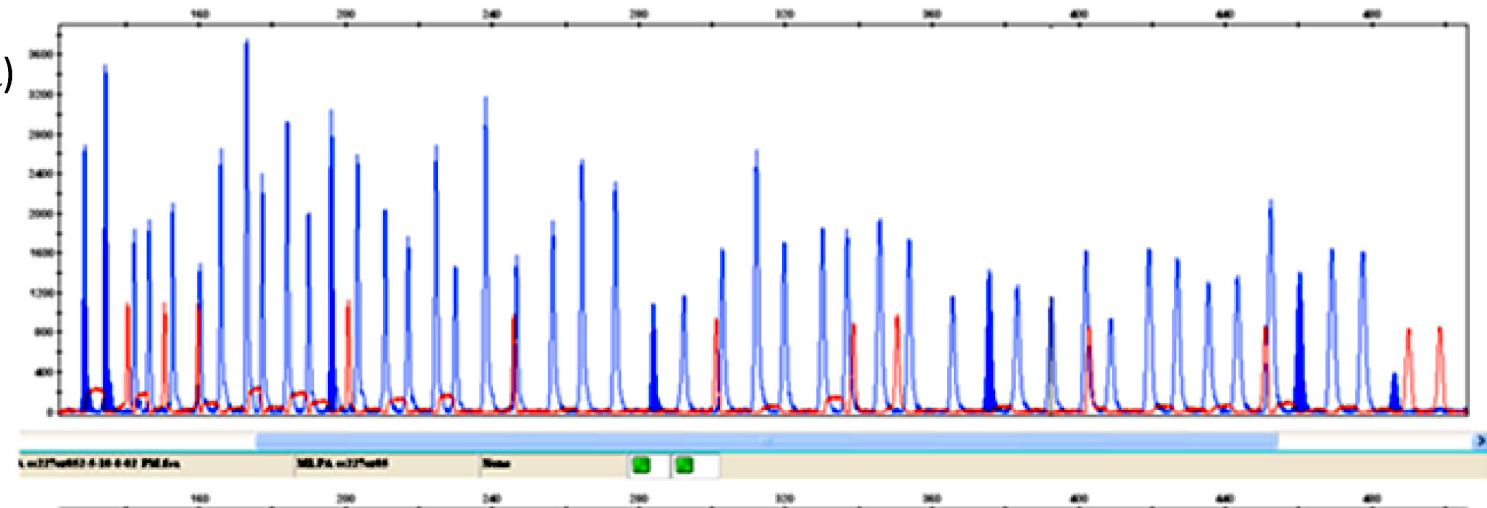

b)

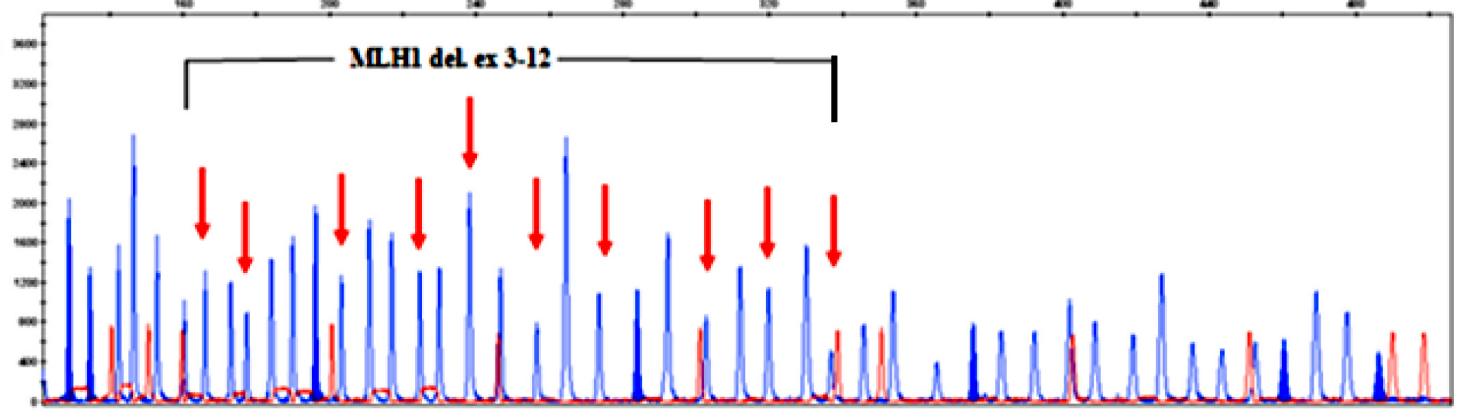

Fig. 1. MLPA-detection of the MLH1 del.ex 3-12 mutation in a patient with the Lynch Syndrome (b) in comparison to a control DNA sample (a). 
$\begin{array}{lllllllllllllllllllllllllllllllllll}\text { A G } & C & T & T & T & T & C & C & T & T & A & A & A & G & T & C & N & C & T & T & C & A & T & T & T & T & T & A & T & T & T & T & C\end{array}$

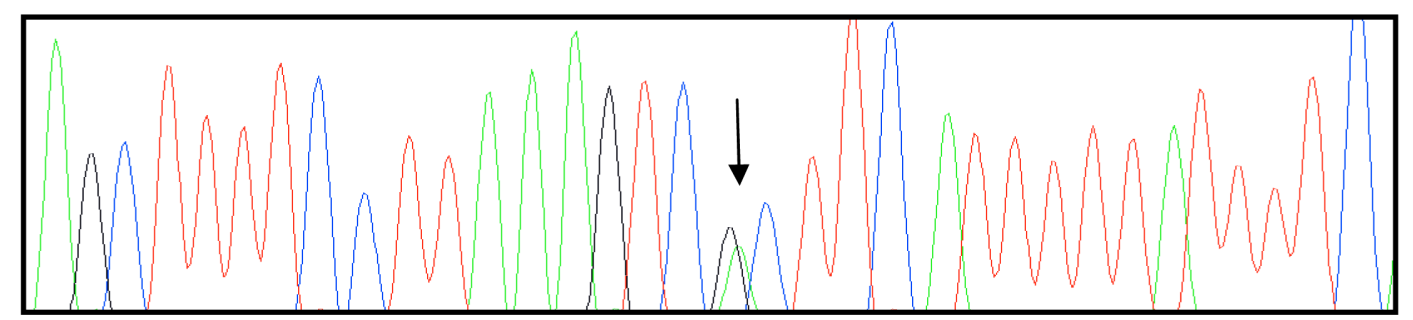

Fig. 2. Electrophoregram corresponding to the sequenced PCR-amplicon of the MLH1 gene in the patient having the mutation IVS14-19A $>$ G

methylated $M L H 1$ promoter could be a sporadic one. But, if MSI and $M L H 1$ promoter hypermethylation are present in both tumors and the genetic testing of the mother confirms the hereditary character of the disease, we might get a strong argument against the hypothesis that somatic promoter hypermethylation of $\mathrm{MLH1}$-gene promoter excludes the Lynch Syndrome diagnosis.

The DNA sequencing-analysis identified a patient with a point DNA-change on the fourteenth intron of $M L H 1$ : IVS14-19A $>$ G (Fig.2), located in the splicing branch site region. This change hasn't been reported in the Human Genome Mutation database (HGMD) as a cause for the Lynch Sy so far. In order to determine the potential impact of this alteration on the posttranscriptional mRNA processing and the existence of an alternative splicing mechanism that would cause production of an aberrant transcript differing in size from the wild type, we performed a RT-PCR reaction on peripheral leukocytes' RNA to achieve reverse transcription and amplification of the investigated region. The obtained DNA-fragment was analyzed by electrophoresis on a $10 \%$ polyacrilamide gel. According to the results presented on the electrophoregram (Fig. 3), we didn't detect an aberrant mRNA-transcript differing in size from the 192bp-long fragments identified among the two wildtype RNA samples. Still, this result doesn't completely exclude the hypothesis for existence of an alternative splicing mechanism due to the IVS14-19A $>$ G mutation. Namely, aberrant mRNA transcripts longer by 17,19 or $20 \mathrm{bp}$ than the wild type ones, might be degraded by the mechanism of nonsense mediated decay and hense become unidentifiable by this test. Therefore, additional functional tests are warranted to confirm/exclude the deleterious effect of this alteration.

In one patient diagnosed with two metachronous CRCs by the age of 40 , burdened with a heavy familial history of cancer, we identified a germline genetic alteration on the fourth $M L H 1$ intron: IVS4+65A>C (Fig.4) which hasn't been previously reported to be involved in the LS, and considering its location within the gene doesn't appear to have a pathological impact. Further genetic testing of MSH6, EPCAM and PMS2 might confirm the LS-association of this cancer or classify it among the FCC-X type CRCs.

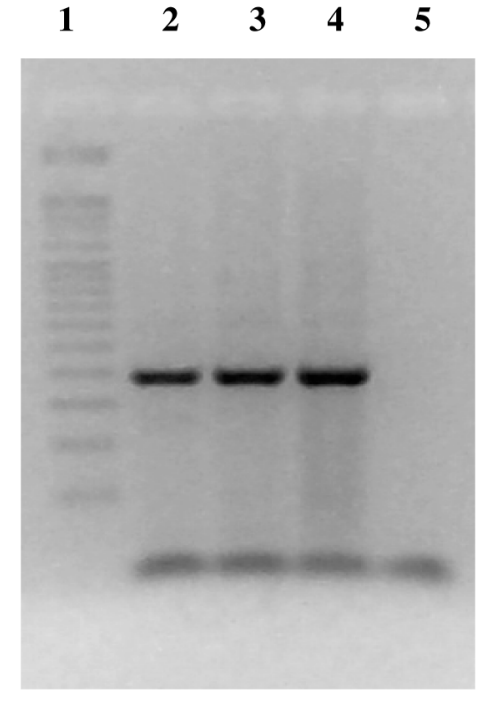

Fig. 3. PAGE electrophoregram of RT-PCR amplicons from: RNA samples corresponding to the patient with the IVS14-19A $>$ G mutation (lane 2) and two control samples (lanes 3 and 4) in comparison to a blank (lane 5) and the molecular size marker StepLadder 50 (lane 1).

We detected the novel missense mutation MLH1 c. $244 \mathrm{~A}>\mathrm{G}, \mathrm{p} . \mathrm{T} 82 \mathrm{~A}$ in one patient diagnosed with a cancer of the ascending colon at an age of 40 , whose mother was also diseased with an early onset CRC. This genetic change leads to a substitution of the polar aminoacid Threonine with the hydrophobic aminoacid Alanine, probably causing a pathogenic effect similar to the c. $245 \mathrm{C}>\mathrm{T}$ mutation already reported in the HGMD.

In $7 / 8$ patients $(87.5 \%)$, we detected the c. $655 \mathrm{~A}>\mathrm{G}$ point mutation in the eighth exon of MLH1 (Fig.5) causing synthesis of a polypeptide with a substitution of Iseleucine with Valine at position 219 (p.Ile219Val). One of these patients holds this genetic variant in a homozygous form, the remaining are being heterozygous. This genetic variation has been previously reported as a polymorphism in the general population (Liu, 1995), but Tomlinson and his col- 
a) TATT T T T T G C C TAGG TCTCA G A G TAATC CT G T CTCA

b)

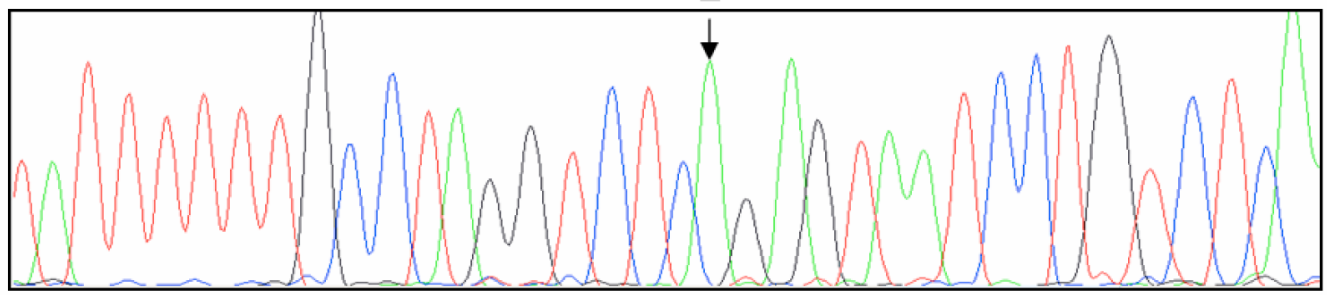

TATT T T TTGCC TAGG TCTCNGAGTAATCCTG TCTCA

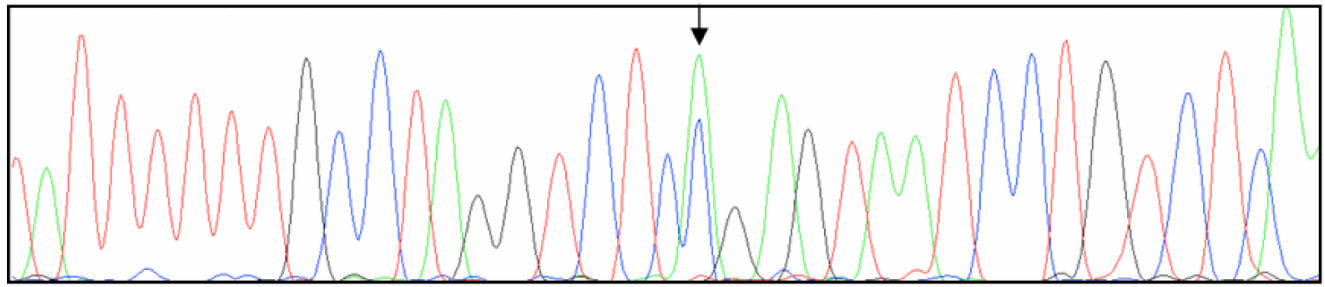

Fig. 4. Electrophoregrams corresponding to a) control genomic DNA and b) DNA sample of a patient with the IVS4+65A $>C$ mutation.

a)

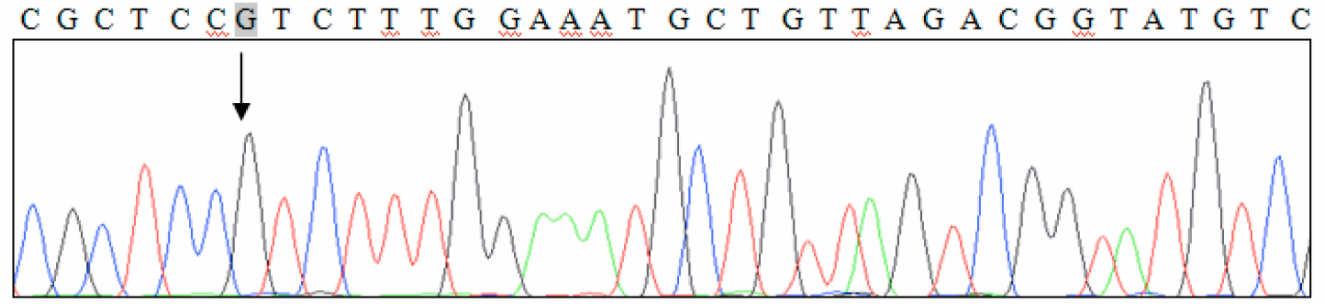

b)

C G C T C C N T C T T T G GAAA T G C T G T T A G A C G G T A T G T C

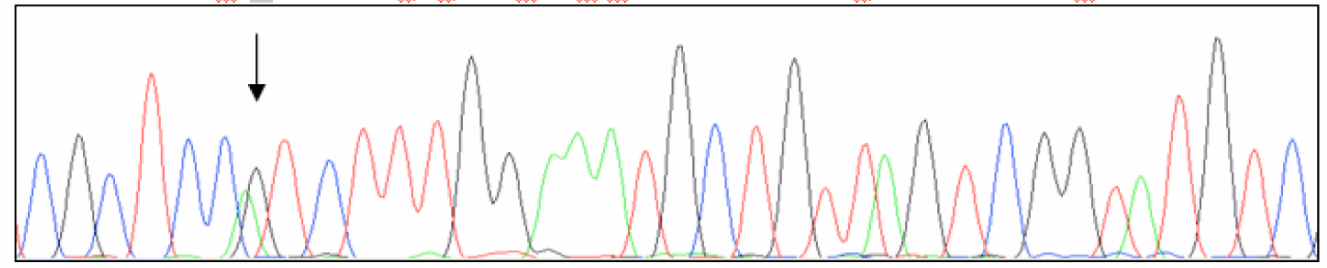

C G C T C CA T C T T T G GAAA T G C T G T T A G A C G G T A T G T C

c)

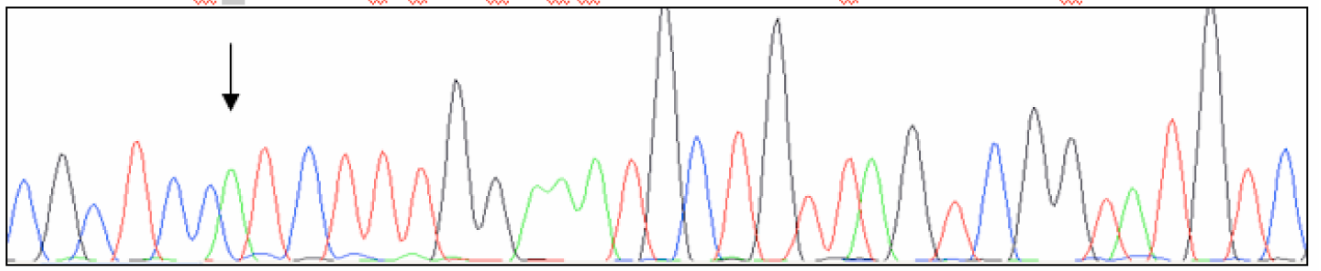

Fig. 5. Detection of the Ile219Val genetic variant in a homozygous (a) and heterozygous (b) form in comparison to a control sample (c).

laborators (Tomlinson et al., 1997) suggest that this change with a frequency of $1 \%$ should be treated as a low penetrant mutation for development of CRC. The Ile219Val change is located in a conserved region of the eighth $M L H 1$ exon, hence it is quite rational to expect its impact on development of pathological consequences. According to the functional analyses performed so far, the products of the wild-type and polymorphic allele poses similar DNAreparative activity (Trojan et al., 2002; Raevaara et al., 2005), but these tests do not address the stability of the proteins which also might be a cause for their impaired activity. Evidence indicating that this change is not totally be- 
nign exist. Some of them even suggesting it to be a predictor of a high mutation frequency haplotype (Hutter et al., 2000, 2002). Furthermore, homozygosity for this variation is associated with reduced expression of the MLH1 protein in sporadic CRCs in Korea (Kim et al., 2004). According to several published studies (Berndt et al., 2007; Yu et al., 2006), Ile219Val is not associated with colonic cancers itself, but the western diet modifies this association in a way that $219 \mathrm{Val} / \mathrm{Val}$ genotype in patients on a western diet (red overroasted meat, fast food, eggs, full-fat dairy products, refined cereals and sugar) is associated with a two-fold increased risk for CRC development in comparison to individuals of the Ile/Ile genotype avoiding the western diet (Campbell, 2009). Additionally, the Ile219Val variant is associated with 5 times higher risk of ulcerative colitis (Bagnoli et al., 2004) which is a risk factor for CRC development itself.

\section{Conclusions}

The molecular profiling of LS among patients with CRC from the Republic of Macedonia has identified the causative deletion MLH1 del.ex3-12 and the novel, possibly founder, nonsense mutation MLH1 c.392C $>$ G and suggests plausible involvement of the c.244A $>\mathrm{G}$ missense mutation, the intronic changes: IVS14-19A $>\mathrm{G}$ and IVS4 $+65 \mathrm{~A}>\mathrm{C}$ as well as the Ile219Val genetic variant within $M L H 1$ in the development of this syndrome. The vast majority of the clinically suspected LS patients are most probably cases with the hereditary syndrome recently proposed by Valle, or cases with a familial cancer of unknown etiology. Focusing the further genetic analyses on these patients might reveal new genes with high or low penetrance for development of colorectal cancer.

\section{References}

Aaltonen, L.A., Salovaara, R., Kristo, P., Canzian, F., Hemminki, A., Peltomaki, P., Chadwick, RB., Kaariainen, H., Eskelinen, M., Jarvinen, H., Mecklin, JP., de la Chapelle, A., 1998. Incidence of hereditary nonpolyposis colorectal cancer and the feasibility of molecular screening for the disease. N. Engl. J. Med. 338(21);1481-1487.

Aarnio, M., Sankila, R., Pukkala, E., Salovaara, R., Aaltonen, LA., de la Chapelle, A., Peltomaki, P., Mecklin, JP., Jarvinen HJ., 1999. Cancer risk in mutation carriers of DNA-mismatchrepair genes. Int. J. Cancer. 81(2):214-218.

Bagnoli, S., Putignano, AL., Melean, G., Baglioni, S., Sestini, R., Milla, M., d'Albasio, G., Genuardi, M., Pacini, F., Trallori, G., Papi, L., 2004. Susceptibility to refractory ulcerative colitis is associated with polymorphism in the hMLH1 mismatch repair gene. Inflamm Bowel Dis. 10(6):705-708.

Bellizzi, AM., Frankel, WL., 2009. Colorectal cancer due to deficiency in DNA mismatch repair function: a review. Adv Anat Pathol. 16:405-417.

Berndt, SI., Platz, EA., Fallin, MD., Thuita, LW., Hoffman, SC., Helzlsouer, KJ., 2007. Mismatch repair polymorphisms and the risk of colorectal cancer. Int. J. Cancer. 120(7):15481554.

Boland, CR., Thibodeau, SN., Hamilton, SR., Sidransky, D., Eshleman, JR., Burt, RW., Meltzer, SJ., Rodriguez-Bigas, MA., Fodde, R., Ranzani, GN., Srivastava, S., 1998. A National Cancer Institute Workshop on Microsatellite Instability for cancer detection and familial predisposition: development of international criteria for the determination of microsatellite instability in colorectal cancer. Cancer Res. 15; 58(22):5248-5257.

Bouzourene, H., Hutter, P., Losi, L., Martin, P., Benhattar, J., 2010. Selection of patients with germline MLH1 mutated Lynch syndrome by determination of MLH1 methylation and BRAF mutation. Fam Cancer. 9:167-172.

Cruz-Correa, M., Giardiello, FM., 2002. Diagnosis and management of hereditary colon cancer. Gastroenterol. Clin. North. Am. 31(2): 537-549.

Campbell, PT., Curtin, K., Ulrich, CM., Samowitz, WS., Bigler, J., Velicer, CM., Caan, B., Potter, JD., Slattery, ML., 2009. Mismatch repair polymorphisms and risk of colon cancer, tumour microsatellite instability and interactions with lifestyle factors. Gut. 58(5): 661-667.

Hiljadnikova-Bajro, M., Josifovski, T., Panovski, M., Dimovski, AJ., 2012. A novel germline MLH1 mutation causing Lynch Syndrome in patients from the Republic of Macedonia. Croat Med J. 53 (5):496-501. http://www.hgmd.cf.ac.uk/ac/index. php assessed at 18.05.2012

Jasperson, KW., Tuohy, TM., Neklason, DW., Burt, RW., 2010. Hereditary and familial colon cancer. Gastroenterology. 138(6):2044-2058

Jass, JR., 2006. Hereditary Non-Polyposis Colorectal Cancer: the rise and fall of a confusing term. World J. Gastroenterol. 12(31):4943-4950.

Kim, JC., Roh, SA., Koo, KH., Ka, IH., Kim, HC., Yu, CS., Lee, KH., Kim, JS., Lee, HI., Bodmer, WF., 2004. Genotyping possible polymorphic variants of human mismatch repair genes in healthy Korean individuals and sporadic colorectal cancer patients. Fam Cancer. 3(2):129-137.

Lindor, NM., Rabe, K., Petersen, GM., Haile, R., Casey, G., Baron, J., Gallinger, S., Bapat, B., Aronson, M., Hopper, J., Jass, J., LeMarchand, L., Grove, J., Potter, J., Newcomb, P., Terdiman, JP., Conrad, P., Moslein, G., Goldberg, R., Ziogas, A., Anton-Culver, H., de Andrade, M., Siegmund, K.., Thibodeau, SN., Boardman, LA., Seminara, D., 2005. Lower cancer incidence in Amsterdam-I criteria families without mismatch repair deficiency: familial colorectal cancer type X. JAMA293(16):1979-1985.

Liu, B., Nicolaides, NC., Markowitz, S., Willson, JK., Parsons, RE., Jen, J., Papadopolous, N., Peltomäki, P., de la Chapelle, A., Hamilton, SR., Kinzler, KW., Vogelstein, B., 1995. Mismatch repair gene defects in sporadic colorectal cancers with microsatellite instability. Nat. Genet. 9(1): 48-55.

Llor, X., Pons, E., Xicola, RM., Castells, A., Alenda, C., Piñol, V., Andreu, M., Castellví-Bel, S., Payá, A., Jover, R., Bessa, X., Girós, A., Roca, A., Gassull, MA., 2005. Gastrointestinal Oncology Group of the Spanish Gastroenterological Association. Differential features of colorectal cancers fulfilling Amsterdam criteria without involvement of the mutator pathway. Clin. Cancer. Res.11(20):7304-7310.

Mueller-Koch, Y., Vogelsang, H., Kopp, R., Lohse, P., Keller, G., Aust, D., Muders, M., Gross, M., Daum, J., Schiemann ,U., Grabowski, M., Scholz, M., Kerker, B., Becker, I., Henke, G., Holinski- Feder, E., 2005. Hereditary non-polyposis 
colorectal cancer: clinical and molecular evidence for a new entity of hereditary colorectal cancer. Gut. 54(12):17331740.

National Cancer Institute, Genetics of Colorectal Cancer (PDQ), Health Professional Version, last modified 2012, assessed at 18.05.2011; http://www.cancer.gov/cancertopics/pdq/ genetics/colorectal/HealthProfessional

Palomaki, GE., McClain, MR., Melillo, S., Hampel, HL., Thibodeau, SN., 2009. EGAPP supplementary evidence review: DNA testing strategies aimed at reducing morbidity and mortality from Lynch syndrome. Genet Med. 11(1):4265 .

Parsons, MT., Buchanan, DD., Thompson, B., Young, JP., Spurdle, AB., 2012. Correlation of tumour BRAF mutations and MLH1 methylation with germline mismatch repair (MMR) gene mutation status: a literature review assessing utility of tumour features for MMR variant classification. J. Med. Genet. 49(3):151-157

Raevaara, TE., Korhonen, MK., Lohi, H., Hampel, H., Lynch, E., Lönnqvist, KE., Holinski-Feder, E., Sutter, C., McKinnon, W., Duraisamy, S., Gerdes, AM., Peltomäki, P., KohonenCcorish, M., Mangold, E., Macrae, F., Greenblatt, M., de la Chapelle, A., Nyström, M., 2005. Functional significance and clinical phenotype of nontruncating mismatch repair variants of MLH1. Gastroenterology 129(2):537-549.

Risinger, J.I., Barrett, J.C., Watson, P., Lynch, H.T., Boyd, J., 1996. Molecular genetic evidence of the occurrence of breast cancer as an integral tumor in patients with the hereditary nonpolyposis colorectal carcinoma syndrome. Cancer. 77(9):1836-1843.

Rodriguez-Bigas, MA., Boland, CR., Hamilton, SR., Henson, DE., Jass, JR., Khan, PM., Lynch, H., Perucho, M., Smyrk, T., Sobin, L., Srivastava, S., 1997. A National Cancer Institute Workshop on Hereditary Nonpolyposis Colorectal Cancer Syndrome: meeting highlights and Bethesda guidelines. J. Natl. Cancer Inst. 89(23):1758-1762.

Sambrook, J., Fritsch, EF., Maniatis, T., 1989. Molecular Cloning - A Laboratory Manual, $2^{\text {nd }}$ Edition. Cold Spring Habour Laboratory Press, New York.

Schouten, JP., McElgunn, CJ., Waaijer, R., Zwijnenburg, D., Diepvens, F., Pals, G., 2002. Relative quantification of 40 nucleic acid sequences by multiplex ligation-dependent probe amplification. Nucleic Acids Res. 30(12):e57.
Shia J., 2008. Immunohistochemistry versus microsatellite instability testing for screening colorectal cancer patients at risk for hereditary nonpolyposis colorectal cancer syndrome. Part 1: The utility of immunohistochemistry. J. Mol. Diagn. 10: 293-300.

Tomlinson, IP., Beck, NE., Homfray, T., Harocopos, CJ., Bodmer, WF., 1997. Germline HNPCC gene variants have little influence on the risk for sporadic colorectal cancer. J. Med. Genet. 34(1):39-42.

Trojan, J., Zeuzem, S., Randolph, A., Hemmerle, C., Brieger, A., Raedle, J., Plotz, G., Jiricny, J., Marra, G., 2002. Functional analysis of hMLH1 variants and HNPCC-related mutations using a human expression system. Gastroenterology 122(1): 211-219.

Umar, A., Boland, CR., Terdiman, JP., Syngal, S., de la Chapelle, A., Ruschoff, J., Fishel, R., Lindor, NM., Burgart, LJ., Hamelin, R., Hamilton, SR., Hiatt, RA., Jass, J., Lindblom, A., Lynch, HT., Peltomaki, P., Ramsey, SD., RodriguezBigas, MA., Vasen, HF., Hawk, ET., Barrett, JC., Freedman, AN., Srivastava, S., 2004. Revised Bethesda Guidelines for hereditary nonpolyposis colorectal cancer (Lynch syndrome) and microsatellite instability. J. Natl. Cancer Inst. 96(4):261268.

Valle, L., Perea, J., Carbonell, P., Fernandez, V., Dotor, AM., Benitez, J., Urioste, M., 2007. Clinicopathologic and pedigree differences in Amsterdam I-positive hereditary nonpolyposis colorectal cancer families according to tumor microsatellite instability status. J. Clin. Oncol. 25(7):781-786.

Vasen, HF., Mecklin, JP., Khan, PM., Lynch, HT., 1991. The International Collaborative Group on Hereditary NonPolyposis Colorectal Cancer (ICG-HNPCC). Dis Colon Rectum. 34(5):424-425.

Vasen, HF., Mecklin, JP., Khan, PM., Lynch, HT., 1994. The International Collaborative Group on HNPCC. Anticancer Res. 14(4B):1661-1664

Watson, P., Lynch, HT., 1994. The tumor spectrum in HNPCC. Anticancer Res. 14(4B):1635-1639. Xiong, Z., Laird, PW., 1997. COBRA: a sensitive and quantitative DNA methylation assay. Nucleic Acids Res. 25(12):2532-2534.

Yu, JH., Bigler, J., Whitton, J., Potter, JD., Ulrich, CM., 2006. Mismatch repair polymorphisms and colorectal polyps: hMLH1-93G $>$ A variant modifies risk associated with smoking. Am. J. Gastroenterol. 101(6):1313-1319. 


\title{
Резиме
}

\section{Молекуларен профил на Линч Синдромот во Република Македонија}

\author{
Марија Хиљадникова-Бајро', Тони Јосифовски², Милчо Пановски², \\ Александар Ј. Димовски ${ }^{3 *}$ \\ ${ }^{1}$ Институт за применета биохемија, Фармацевтски факултет, Универзитет „Св. Кирил и Методиј“, Скопје, \\ Република Македонија \\ ${ }^{2}$ Универзитетска клиника за дигестивна хирургија, Медицински факултет, Универзитет „Св. Кирил и Методиј“, \\ Скопје, Република Македонија \\ $3^{3 *}$ Центар за биомолекуларни фармацевтски анализи, Фармацевтски факултет, Универзитет „Св. Кирил и \\ Методиј“, Скопје, Република Македонија
}

Клучни зборови: Колоректален карцином, Линч синдром, $M L H 1$, микросателитска нестабилност

Најзастапениот тип на наследен колоректален карцином, карактеристичен за Линч синдромот (ЛС), се смета за фенотипска манифестација на генетски дефект во механизмот за репарација на несоодветно спарување на бази при ДНК репликација, односно во MLH1, MSH2, MSH6 или PMS2 генот. Во рамките на нашите напори за воспоставување на стандардизиран протокол што ќе вклучува молекуларни анализи за дијагноза на овој синдром и формирање на единствен национален регистер на семејства со наследни синдроми на колоректален карцином во Република Македонија, отпочнавме проспективна студија за разоткривање на генетските дефекти кај Македонските пациенти со колоректален карцином (КРК) и идентификација на семејства со наследен КРК.

Вкупно 53 пациенти кои ги исполнуваат ревидираните Бетезда критериуми за генетско тестирање за Линч синдромот беа споредени со 350 пациенти со спорадичен КРК. Резултатите покажуваат сигнификанти разлики во однос на возраста при дијагноза $(\mathrm{p}=0,03)$, инволвираност на микросателитската нестабилност $(\mathrm{p}<0,001)$ и локализација на туморот во однос на flexura lienalis $(\mathrm{p}=0,009)$ и сугерираат припадност на повеќето од „Бетезда+““ КРКи кон групата позната како Фамилијарен Колоректален карцином од тип „X“. Со молекуларната карактеризација на ЛС-суспектите идентификувавме нова MLH1 c.392C>G nonsense мутација со потенцијален „founder“ ефект кај Македонската популација и MLH1 ех.3-12 делецијата, како и с.244 A>G мутацијата, IVS14$19 \mathrm{~A}>\mathrm{G}$ и IVS4+65A>C промените без потврдено патолошко значење. Високата фреквенција (87.5\%) на Ile219Val (c.655A>G) варијантата во $M L H 1$ забележана кај ЛС суспектите ја наложува потребата од дополнителни аналзи за евалуирање на нејзината инволвираност во развојот на наследен КРК како самостоен ризик фактор или модификатор на ризикот кај пациентите од Република Македонија. 